\title{
Effect of Light Intensity on Leaf
}

Photosynthetic Characteristics and

Accumulation of Flavonoids in

\section{Lithocarpus litseifolius (Hance) Chun. (Fagaceae)}

\author{
Aimin Li1 ${ }^{1,2,3^{*}}$, Shenghua Li1,2,3*, Xianjin Wu1,2,3\#, Jian Zhang1,2,3, Anna He ${ }^{1,2,3}$, Guang Zhao1, Xu Yang1 \\ ${ }^{1}$ College of Biological and Food Engineering, Huaihua University, Huaihua, China \\ ${ }^{2}$ Key Laboratory of Research and Utilization of Ethnomedicinal Plant Resources of Hunan Province, Huaihua University, \\ Huaihua, China \\ ${ }^{3}$ Key Laboratory of Xiangxi Medicinal Plant and Ethnobotany of Hunan Higher Education, Huaihua University, \\ Huaihua, China \\ Email: \#hhuxianjin@163.com
}

How to cite this paper: Li, A.M., Li, S.H., Wu, X.J., Zhang, J., He, A.N., Zhao, G. and Yang, X. (2016) Effect of Light Intensity on Leaf Photosynthetic Characteristics and Accumulation of Flavonoids in Lithocarpus litseifolius (Hance) Chun. (Fagaceae). Open Journal of Forestry, 6, 445-459. http://dx.doi.org/10.4236/ojf.2016.65034

Received: August 29, 2016

Accepted: October 10, 2016

Published: October 13, 2016

Copyright $\odot 2016$ by authors and Scientific Research Publishing Inc. This work is licensed under the Creative Commons Attribution International License (CC BY 4.0).

http://creativecommons.org/licenses/by/4.0/ (c) (i) Open Access

\begin{abstract}
The active compounds in herb drugs are mainly secondary metabolites, which are greatly influenced by external conditions. Particularly, light intensity has a great influence on the photosynthesis and accumulation of secondary metabolites. In this study, the light intensity was changed, and the influence of the light intensity on leaf photosynthetic characteristics, antioxidant enzyme activity and flavone contents of Lithocarpus litseifoliusp (Hance) Chun. was discussed. The results showed that (1) L. litseifolius is a typical heliophyte. As the light intensity decreased, the contents of chlorophyll a (Chl a), chlorophyll b ( Chl b) and total chlorophyll $(\mathrm{Chl} a+b)$ all increased. However, the $\mathrm{Chl} \mathrm{a} / \mathrm{b}$ ratio gradually decreased. The daily variation of net photosynthetic rate changed from a double-peak curve under natural light to singlepeak curve under $20 \%$ full light two shading nets. (2) As the light intensity decreased, the SOD and POD activities and the soluble proteins content decreased in the leaves. In contrast, the malondialdehyde content increased. (3) The flavone content was the highest in leaves at one shading nets $60 \%$ of full light, and the lowest occurred in leaves at two shading nets $20 \%$ of full light. A comprehensive analysis indicated that an appropriate shading could induce shade tolerance in the leaves of L. litseifolius, which promoted the accumulation of flavonoids. L. litseifolius should be planted in the lower position of sunny slope or the upper position of shady slope to increase the content of flavone in the leaves.
\end{abstract}

\footnotetext{
${ }^{\star}$ These authors contributed equally to this study.
} 


\section{Keywords}

Lithocarpus litseifolius (Hance) Chun., Light Intensity, Photosynthetic

Characteristics, Antioxidant Enzyme Activity, Flavones Content, Cultivation

\section{Introduction}

Environmental changes can lead to changes of shape, surface characteristics, curl degree and anatomical characteristics of leaves. Light is one of the most important environmental factors affecting the growth and development of plants (Pengelly et al., 2010; Jiang et al., 2011). Light not only influences the morphology of a single leaf, but also the overall plant morphology. The plant can adapt to the light intensity changes by changing biomass distribution and its own morphology, so as to maximally utilize the light energy and survive (Xue, 2001; Hu et al., 2006).

Changes in light intensity can influence leaf photosynthesis. Under weak light, the contents of photosynthetic pigments, especially chlorophyll (Chl) b, will increase. Simultaneously, the chlorophyll $\mathrm{a} / \mathrm{b}$ ratio $(\mathrm{Chl} \mathrm{a/b})$ decreases, accompanied by a decline in maximum net photosynthetic rate (Liu et al., 2012; Wang et al., 2012). Under strong light conditions, the excess photons absorbed by pigments will not be completely consumed in photosynthesis. As a result, photoinhibition occurs (Shirke \& Pathre, 2003), leading to the generation of a large amount of reactive oxygen species (ROS) and hence oxidative stress. The antioxidant enzymes in plants can scavenge the superoxide anion radicals (Maruta et al., 2010). Studies have shown that light intensity has a significant impact on the contents of such secondary metabolites as alkaloids (Zhao et al., 2001; Dai et al., 2004), sesquiterpenes (Hägele et al., 1999), salidroside (Yan et al., 2003, 2004), flavonoid glycosides and terpene lactone (Leng et al., 2002; Gavin \& Durako, 2012).

Lithocarpus litseifolius (Hance) Chun., family Fagaceae, is also known as sweet tea. As an evergreen plant, L. litseifolius can simultaneously be consumed as a drug and a food (He et al., 2012a, 2012b). It is primarily found in mountainous regions of Jiangxi, Guangxi and Hunan, China, as a common evergreen tree species that is heliophilic and can resist drought (Chen \& Huang, 1998). The tender leaves of L. litseifolius are used as traditional Chinese medicine with the functions of clearing heat, promoting diuresis and preventing ulcers, sores and damp-heat dysentery (Xie, 1987). L. litseifolius has been used for more than 1000 years, exhibiting unique efficacy in lowering blood glucose and lipid levels and blood pressure (Hou et al., 2011; Dong et al., 2012). The main active components are flavonoids ( $\mathrm{Li}$ et al., 2008). Existing studies on L. litseifolius have mostly concerned the extraction and isolation of flavonoids from leaves (Li et al., 2008, 2010) and their applications (Ren et al., 2012). To avoid wild natural resources have been exhausted, it is necessary to carry out the standardized cultivation. The present work examined the physiological responses of $L$. litseifolius under different light inten- 
sity, in order to make clear the variation of leaf photosynthetic physiological characteristics and accumulation of flavonoids rule. So we can assessment the influence of different light intensity to growth of L. litseifolius and the accumulation of flavonoids in leaves. Thus, appropriate cultivation conditions were determined for increasing the content of flavonoids in L. litseifolius.

\section{Materials and Methods}

\subsection{Experimental Site}

The experiment was carried out in the Medicinal Herb Garden of the West Campus, Huaihua University, Hunan Province, China (27 $\left.34^{\prime} 38.78^{\prime \prime N}, 110^{\circ} 01^{\prime} 19.44^{\prime \prime E}\right)$. The annual average temperature in this region is $16.4^{\circ} \mathrm{C}$. The precipitation is ample, with annual precipitation of $1027.6-1701.3 \mathrm{~mm}$, and annual sunshine duration is 1303.5 1519.2 h. This region has a humid mid-subtropical monsoon climate.

\subsection{Experimental Materials}

The experiment was carried out in 2010, using 3-year-old L. litseifolius with uniform growth status as the experimental material. The shading treatment was applied with black shading net from 15 March 2010 to 15 March 2011, which was installed at a height of $2.5 \mathrm{~m}$ above the ground. The light intensity was adjusted by changing the number of shading nets, and the value of shading rate was accurately measured with an illuminometer. There were two light intensity treatments: about $60 \%$ and $20 \%$ of natural light, using one or two shading nets, respectively. The control was natural light treatment (i.e. no shading net). Conventional cultivation management was implemented. Six plants were cultivated in each plot, with plant and row spacing of $1.5 \mathrm{~m}$. To avoid mutual shading, the spacing between plots was $1.5 \mathrm{~m}$. There were a total of nine plots, with three replicates per treatment.

\subsection{Determination of Chlorophyll Content}

Following the method of Arnon (1949), the fresh leaves $0.2 \mathrm{~g}$, which 5 days before treatment and after treatment, respectively. Pigments were extracted with $95 \%$ ethanol, then constanted volume to $25 \mathrm{ml}$. Absorbance values were measured with $7230 \mathrm{G}$ spectrophotometer at $665 \mathrm{~nm}, 649 \mathrm{~nm}$ and $470 \mathrm{~nm}$, respectively. Each sample was measured three times and the mean was taken.

\subsection{Determination of Net Photosynthetic Rate}

A LI-6400XT Portable Photosynthesis System was used in open gas path mode. The leaves of $L$. litseifolius (three plants per treatment, four leaves per plant, three measurements per leaf and a total of 36 replicates), which fully developed and similar position, that were fully illuminated were randomly selected from the same leaf position under different shading rates, The net photosynthetic rate $\left(P_{n}\right)$ was measured every $2 \mathrm{~h}$ during 08:00-18:00 in sunny weather (26-31 August) and the daily variation trend of photosynthetic rate was obtained. The net photosynthetic rate was measured at different 
photon flux densities (PFDs, $0-2000 \mu \mathrm{mol} \cdot \mathrm{m}^{-2} \cdot \mathrm{s}^{-1}$ ). The PPFD curve was fitted using the method of Bassman and Zwier (1991).

$$
\begin{gathered}
P_{n}=P_{\text {max }}\left(1-C_{0} \mathrm{e}^{-a P F D / P_{\max }}\right) \\
\mathrm{LCP}=P_{\text {max }} \ln \left(C_{0} / a\right) \\
\mathrm{LSP}=P_{\text {max }} \ln \left(100 C_{0} / a\right)
\end{gathered}
$$

$P_{\max }$ is the maximum net photosynthetic rate, $a$ is a weak light quantum efficiency, that is, apparent quantum efficiency, $C_{0}$ is a measure of the net photosynthetic rate of the weak light tend to be 0 . LCP is light compensation point, LSP is light saturation point.

\subsection{Determination of Antioxidant Enzyme System and Soluble Proteins}

Superoxide dismutase (SOD) activity was measured using the method of Giannopolitis and Ries (1977). $0.5 \mathrm{~g}$ of vein-free leaves were mixed with $2 \mathrm{~mL}$ of $0.1 \mathrm{M}$ phosphate buffer and ground on ice bath. Supernatant was obtained by centrifugation at $10,000 \times \mathrm{g}$ for $30 \mathrm{~min}$, diluted to $10 \mathrm{~mL}$ as crude enzyme and stored at $4^{\circ} \mathrm{C}$ for future use. $0.05 \mathrm{~mL}$ of the crude enzyme was further diluted to $3.0 \mathrm{~mL}$ with water containing $0.3 \mathrm{~mL}$ of each $130 \mathrm{mM}$ methionine, $0.75 \mathrm{mM}$ nitrogen blue tetrazolium (NBT), $0.1 \mathrm{mM}$ EDTA- $\mathrm{Na}_{2}$ and $0.02 \mathrm{mM}$ riboflavin and $1.5 \mathrm{~mL} 0.05 \mathrm{mM}$ phosphate buffer. Enzyme was replaced with PBS buffer in control tubes. One control tube was set in the dark, the other control and the testing tubes were illuminated with $4000 \mathrm{~lx}$ fluorescent light for $20 \mathrm{~min}$. Absorptions at $560 \mathrm{~nm}$ were measured by referencing to the absorption of the unilluminated control tube. Total and specific SOD activities were calculated based on the following equations: total SOD activity $=(\mathrm{ACK}-\mathrm{AE}) \times \mathrm{V} /(0.5 \times \mathrm{ACK} \times \mathrm{W} \times \mathrm{Vt})$, specific SOD activity $=$ total SOD activity/protein content, where ACK was the absorption of illuminated control; AE was the absorption of tested samples; V was the total sample volume [ml]; Vt was the tested sample volume [ml]; W was fresh sample mass (FM) [g]; the unit of protein concentration was $\mathrm{mg}^{-1} \mathrm{~g}^{-1}$ (FM).

Peroxidase (POD) activity was measured by guaiacol method (Chance \& Maehly, 1955). $0.3 \mathrm{~g}$ leaves were mixed with $6 \mathrm{~mL}$ of $0.1 \mathrm{M}$ phosphate buffer ( $\mathrm{pH} 7.0)$ and grind it to homogenate. The solution was centrifuged for $30 \mathrm{~min}$ at $12,000 \mathrm{~g}, 4^{\circ} \mathrm{C}$. The clear supernatant was enzyme and stored at $4^{\circ} \mathrm{C}$ for future use. The reaction mixture was 50 $\mathrm{mL} 0.1 \mathrm{M}$ phosphate buffer, $28 \mu \mathrm{L}$ guaiacol, and $19 \mu \mathrm{L} \mathrm{H}_{2} \mathrm{O}_{2}(30 \% \mathrm{w} / \mathrm{v})$. The absorbance was measured at $470 \mathrm{~nm}$ for $3 \mathrm{~mL}$ enzyme and $3 \mathrm{~mL}$ reaction mixture, respectively. POD activity $=\Delta \mathrm{A}_{470} \times \mathrm{V}_{\mathrm{T}} /\left(\mathrm{W} \times \mathrm{V}_{\mathrm{S}} \times 0.01 \times \mathrm{t}\right), \triangle \mathrm{A}_{470}$ is changes of the absorbance in the reaction time; $V_{T}$ is total extraction enzyme volume; $W$ is the sample weight; $V_{S}$ is the volume of enzyme solution for the determination; $t$ is reaction time.

The malondialdehyde (MDA) content was measured by thiobarbituric acid chromatometry (Buege \& Aust, 1978), 0.3 g leaves were mixed with $2 \mathrm{~mL}$ of $0.05 \mathrm{M}$ phosphate buffer and $5 \mathrm{~mL} 0.5 \%(\mathrm{~W} / \mathrm{V})$ thiobarbituric acid at $100^{\circ} \mathrm{C}$ water bath, then centrifuged for $10 \mathrm{~min}$ at $4000 \mathrm{~g}$. The clear supernatant was collected and stored at $4^{\circ} \mathrm{C}$ for measure. 
The absorbance was measured at $600 \mathrm{~nm}, 532 \mathrm{~nm}$ and $450 \mathrm{~nm}$. MDA content $=[6.452$ $\left.\times\left(D_{532}-D_{600}\right)-0.559 \times D_{450}\right] \times V_{T} / V_{S} \times W ; V_{T}$ is total extraction volume; $V_{S}$ is the volume of solution for the determination; $\mathrm{W}$ is the sample weight.

Soluble protein content by the method of Bradford (1976). $100.0 \mathrm{~g}$ leaves ground into a homogenate, then centrifuged for $10 \mathrm{~min}$ at $4000 \mathrm{~g}, 4^{\circ} \mathrm{C}$. The clear supernatant was mixed with distilled water to $10 \mathrm{~mL}$ as the protein content to be tested. The standard curve was drawn with BSA-standard solution. The absorbance was measured at 595 $\mathrm{nm}$. Soluble protein content $=$ protein quality $\times \mathrm{V}_{\mathrm{T}} / \mathrm{V}_{\mathrm{S}} \times \mathrm{W}$; Protein quality data were obtained according to the standard curve; $\mathrm{V}_{\mathrm{T}}$ is total extraction volume; $\mathrm{V}_{\mathrm{S}}$ is the volume of solution for the determination; $\mathrm{W}$ is the sample weight.

\subsection{Determination of Flavone Content}

Flavone content was measured according to the method of Li et al. (2008). Of leaf samples, $5 \mathrm{~g}$ was weighed, pulverized and ultrasonically extracted. After evaporation, the ethanol was recovered, and the solution was diluted to $100 \mathrm{~mL}$ with water, then $1 \mathrm{~mL}$ of the sample solution was transferred to a $25-\mathrm{mL}$ colorimetric tube. After the addition of $1.0 \mathrm{~mL}$ of $5 \%$ sodium nitrite, the solution was shaken well and stood for $6 \mathrm{~min}$. Then $1.0 \mathrm{~mL}$ of $5 \%$ aluminum chloride was added and shaken well, and the tube stood for 6 $\mathrm{min}$. Then $10 \mathrm{~mL}$ of $1 \mathrm{~mol} / \mathrm{L}$ sodium hydroxide was added, and the water was added to $25 \mathrm{~mL}$. The solution was shaken well and stood for $15 \mathrm{~min}$. The absorbance was measured at $510 \mathrm{~nm}$. Total flavones were calculated using a regression equation.

\subsection{Statistical Analyses}

SPSS13.0 (SPSS) was used for the statistical analysis and normality testing of the data. Single-factor analysis of variance and the multiple comparison of least significant difference (LSD) method were employed.

\section{Results and Analysis}

\subsection{Influence of Light Intensity on the Content of Photosynthetic Pigments}

Chlorophyll traps the light energy used for primary reactions of photosynthesis, and plays an important role in light energy transfer and conversion. Chl a, Chl b and $\mathrm{Chl}$ (a $+\mathrm{b}$ ) all increased with higher shading rates (Figure 1); however, the $\mathrm{Chl} \mathrm{a} / \mathrm{b}$ ratio decreased. This indicated that under weak light conditions, the leaves mainly absorbed the blue-violet and orange light in the diffused light. As the shading rate increased, $\mathrm{Chl}(\mathrm{a}+$ b) of leaves increased. As $\mathrm{Chl} b$ increased, the leaves of L. litseifolius could absorb the scattered light and thus maintain a high photosynthetic rate.

\subsection{Influence of Light Intensity on Photosynthesis}

Light intensity is one of the major environmental factors influencing plant photosynthesis. $\mathrm{P}_{\mathrm{n}}$ decreased as shading rate increased (Figure 2). Under full light conditions, the $\mathrm{P}_{\mathrm{n}}$ of L. litseifolius varied as double-peaked curve, indicating inhibition of photo- 
natural light $\quad-60 \%$ natural light $\quad 20 \%$ natural light

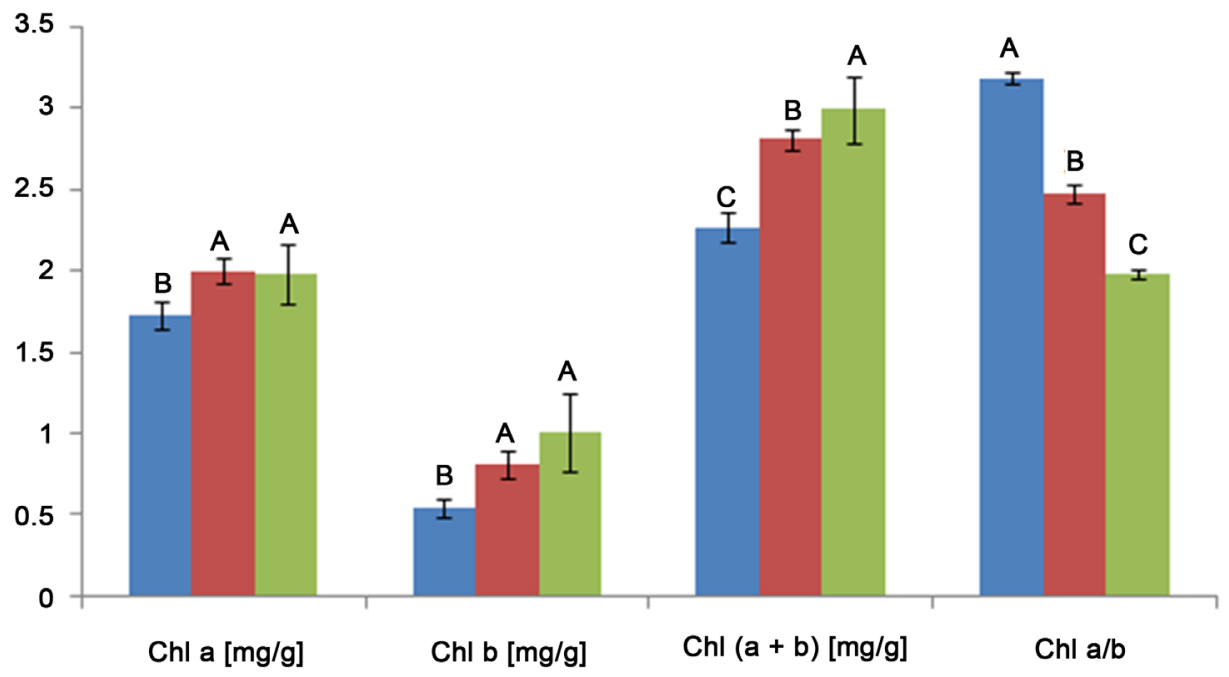

Figure 1. Chlorophyll contents in L. litseifolius leaves under different light treatments. Different letters indicate significant differences under different light treatments plants ( $t$-test, $p<0.05)$.

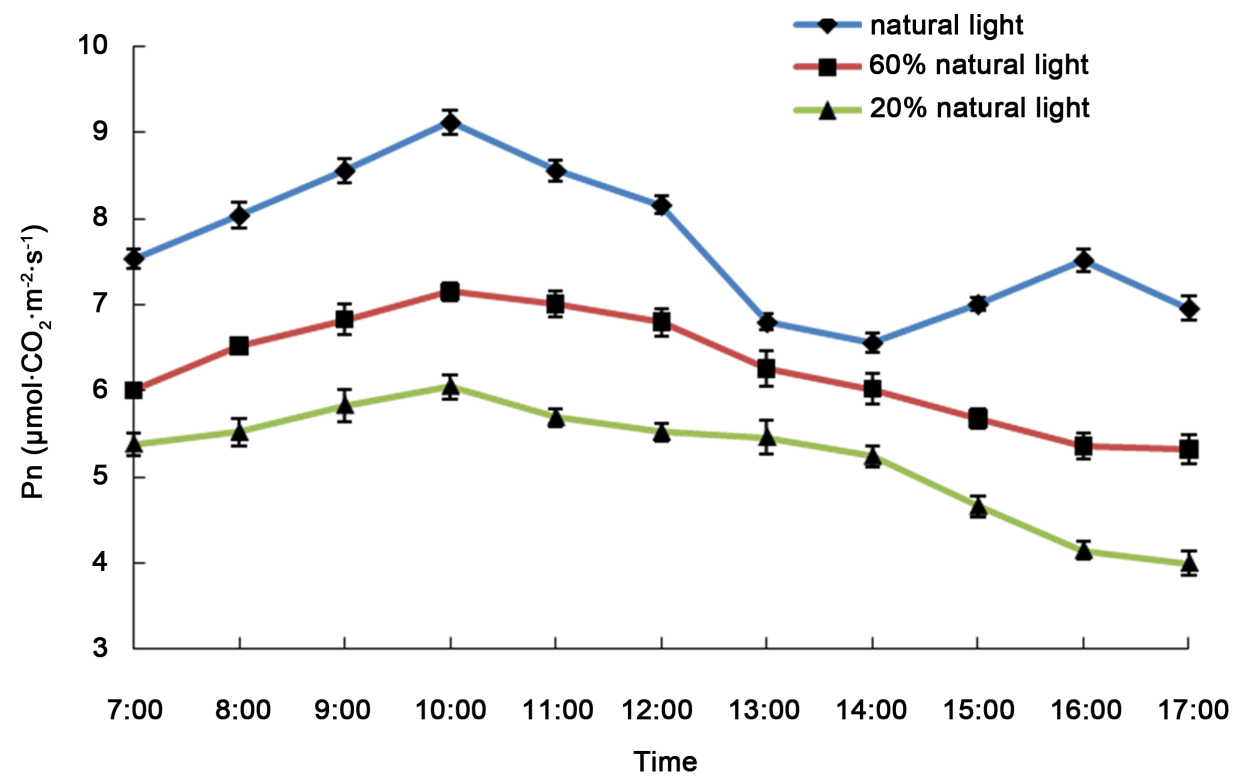

Figure 2. Diurnal variation of photosynthesis rate $\left(\mathrm{P}_{\mathrm{n}}\right)$ under different light treatments in L. litseifolius leaves.

synthesis at noon. With increased shading intensity, $\mathrm{P}_{\mathrm{n}}$ decreased. The daily average $\mathrm{P}_{\mathrm{n}}$ was 7.71, 6.27 and $5.23 \mu \mathrm{mol} \mathrm{CO}_{2} \mathrm{~m}^{-2} \cdot \mathrm{s}^{-1}$ under natural light and $60 \%$ and $20 \%$ natural light, respectively, with significant $(p<0.05)$ differences between the treatments.

\subsection{Photosynthetic Rate-Light Intensity Curve}

Light compensation and saturation points are direct indicators of the capacity of plants to utilize light. They can be used to evaluate the shade tolerance of plants. The light 
response curve of L. litseifolius under different shading rates showed some differences (Figure 3). The results calculated from the P-PFD curve and the corresponding equations are shown in Table 1. The light compensation points under full, $60 \%$ and $20 \%$ natural light occurred at 31,10 and $19 \mu \mathrm{mol} \cdot \mathrm{m}^{-2} \cdot \mathrm{s}^{-1}$, respectively. The saturation points were at 1528,1167 and $1038 \mu \mathrm{mol} \cdot \mathrm{m}^{-2} \cdot \mathrm{s}^{-1}$, corresponding to maximum net photosynthetic rates of 7.8, 6.1 and $5.10 \mu \mathrm{mol} \cdot \mathrm{m}^{-2} \cdot \mathrm{s}^{-1}$. Shading caused declines in light compensation point, saturation point and maximum $\mathrm{P}_{\mathrm{n}}$ to varying extents. The apparent quantum efficiency (AQY) was $0.031,0.042$ and 0.027 , respectively, i.e. $60 \%$ natural light $>$ full light condition $>20 \%$ natural light. A higher AQY indicates an accelerated photosynthetic rate at higher light intensity and a greater sensitivity to light intensity. Of the three treatments, the leaves of $L$. litseifolius were most sensitive to weak light under $60 \%$ natural light.

\subsection{Influence of Light Intensity on Antioxidant Enzyme System and Soluble Proteins}

Shading caused significant declines in SOD and POD activities, as well as a non-significant decline in content of soluble proteins (Table 2). Compared to full light, SOD activity decreased by $7.69 \%$ and $55.78 \%$ as the shading rate increased, respectively; and correspondingly POD activity decreased by $13.66 \%$ and $38.86 \%$. The content of soluble proteins did not decrease significantly, going from $5.48 \mathrm{mg}$ at full light condition to 5.25 and $4.68 \mathrm{mg}$ at $60 \%$ and $20 \%$ natural light, or declining by $3.33 \%$ and $14.8 \%$, respectively. MDA content showed an increasing trend with increased shading rate, i.e. by $7.93 \%$ and $33.3 \%$, respectively, compared to full light.

Table 1. Light response characteristics in L. litseifolius leaves under different light treatments (means $\pm \mathrm{SE}$ ).

\begin{tabular}{cccc}
\hline Parameters & Full light & $60 \%$ Full light & 20\% Full light \\
\hline $\mathrm{P}_{\max }\left(\mu \mathrm{mol} \mathrm{CO} \cdot \mathrm{m}^{-2} \cdot \mathrm{s}^{-1}\right)$ & $7.48 \pm 0.45$ & $6.03 \pm 0.65$ & $5.10 \pm 0.48$ \\
Light compensation point $\left(\mu \mathrm{mol}\right.$ photons $\left.\cdot \mathrm{m}^{-2} \cdot \mathrm{s}^{-1}\right)$ & $31.5 \pm 5.5$ & $10.4 \pm 4.3$ & $19.5 \pm 3.8$ \\
Light saturation point $\left(\mu \mathrm{mol}\right.$ photons $\left.\cdot \mathrm{m}^{-2} \cdot \mathrm{s}^{-1}\right)$ & $1568 \pm 112$ & $1187 \pm 234$ & $1028 \pm 108$ \\
Apparent quantum yield $\left(\mathrm{mmolCO} \cdot \mathrm{mol}\right.$ photons $\left.^{-1}\right)$ & $0.031 \pm 0.03$ & $0.042 \pm 0.05$ & $0.027 \pm 0.06$ \\
\hline
\end{tabular}

Table 2. Antioxidant enzyme system in L. litseifolius leaves under different light treatments (means \pm SE). Different letters indicate significant differences under different light treatments plants $(t$-test, $\mathrm{p}<0.05$ and $p<0.01)$.

\begin{tabular}{ccccc}
\hline Treatment & SOD $\left(\mathrm{U} \cdot \mathrm{g}^{-1} \mathrm{FW}\right)$ & POD $(\mathrm{U} \cdot \mathrm{g} \cdot \mathrm{min} \mathrm{FW})$ & $\mathrm{MDA}\left(\mathrm{nmol} \cdot \mathrm{g}^{-1} \mathrm{FW}\right)$ & Soluble protein $(\mathrm{mg})$ \\
\hline Full light & $520 \pm 5.8^{\mathrm{Aa}}$ & $1100 \pm 6.5^{\mathrm{Ac}}$ & $6.3 \pm 0.5^{\mathrm{Aa}}$ & $5.43 \pm 008^{\mathrm{Bb}}$ \\
$60 \%$ Full light & $480 \pm 6.4^{\mathrm{Bb}}$ & $950 \pm 7.4^{\mathrm{Bb}}$ & $6.8 \pm 0.9^{\mathrm{Bb}}$ & $5.25 \pm 0.04^{\mathrm{Aa}}$ \\
$20 \%$ Full light & $230 \pm 4.8^{\mathrm{Cc}}$ & $670 \pm 8.4^{\mathrm{Bc}}$ & $8.4 \pm 0.5^{\mathrm{Cc}}$ & $4.63 \pm 0.06^{\mathrm{Cc}}$ \\
\hline
\end{tabular}

Note: Different uppercase and lowercase letters in the same column indicate significant differences of parameters under different light treatments at 0.05 and 0.01 levels, respectively. 


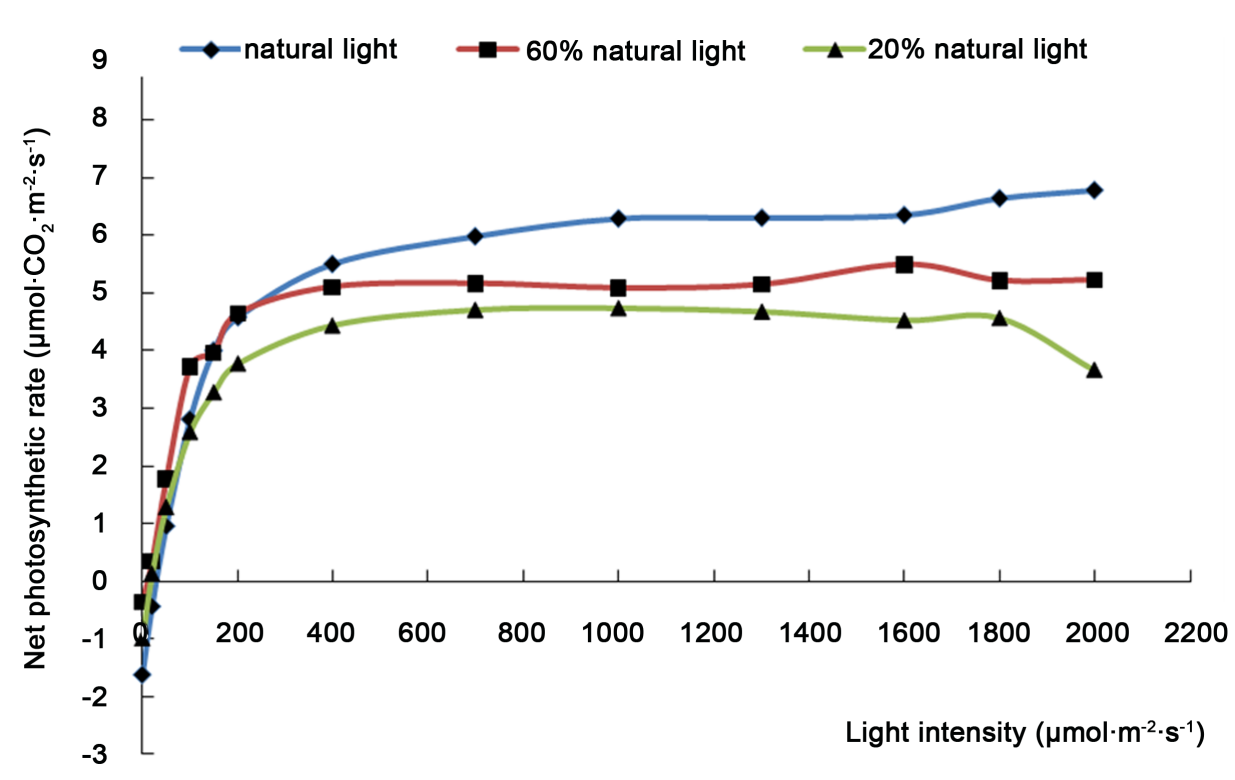

Figure 3. The photosynthetic light response curves of $L$. litseifolius under different light treatments.

\subsection{Influence of Light Intensity on Accumulation of Flavones}

Shading affected flavone concentration in leaves (Figure 4). The flavone content of leaves was highest and lowest at $60 \%$ and $20 \%$ natural light, respectively. This indicated that appropriate shading was favorable for accumulation of total flavones in leaves of $L$. litseifolius. As the light intensity decreased, the accumulation of total flavones was inhibited. As the time of shading treatment was prolonged, the flavone content first increased and then decreased. Total flavones were determined after $60 \mathrm{~d}$ of shading treatment in the different groups. The total flavone was highest $(12.25 \%)$ in leaves under $60 \%$ natural light, and lowest under $20 \%$ natural light, which was only $7.64 \%$. The total flavone content under full light conditions was intermediate, with $10.25 \%$.

\section{Discussion}

\subsection{Influence of Light Intensity on Leaf Photosynthesis of L. litseifolius}

The light compensation point is a direct indicator of the ability to utilize weak light. The lower the light compensation point, the easier photosynthesis will be under weak light conditions. Light intensity exceeds the light compensation point, as light intensity increases, photosynthetic rate is gradually increased, and photosynthetic rate is more than respiration intensity, which promotes the accumulation of organic matter in plants. A lower light saturation point usually indicates that the photosynthetic rate rapidly reaches a maximum as photosynthetically active radiation increases. Shading caused a decline in light compensation and saturation points of leaves of L. litseifolius, shows that $L$. litseifolius could fully utilize weak light for photosynthesis. Apparent quantum yield (AQY) reflects the photosynthetic capacity of leaves under weak light conditions. A higher AQY indicates a greater amount of light-harvesting complex for 


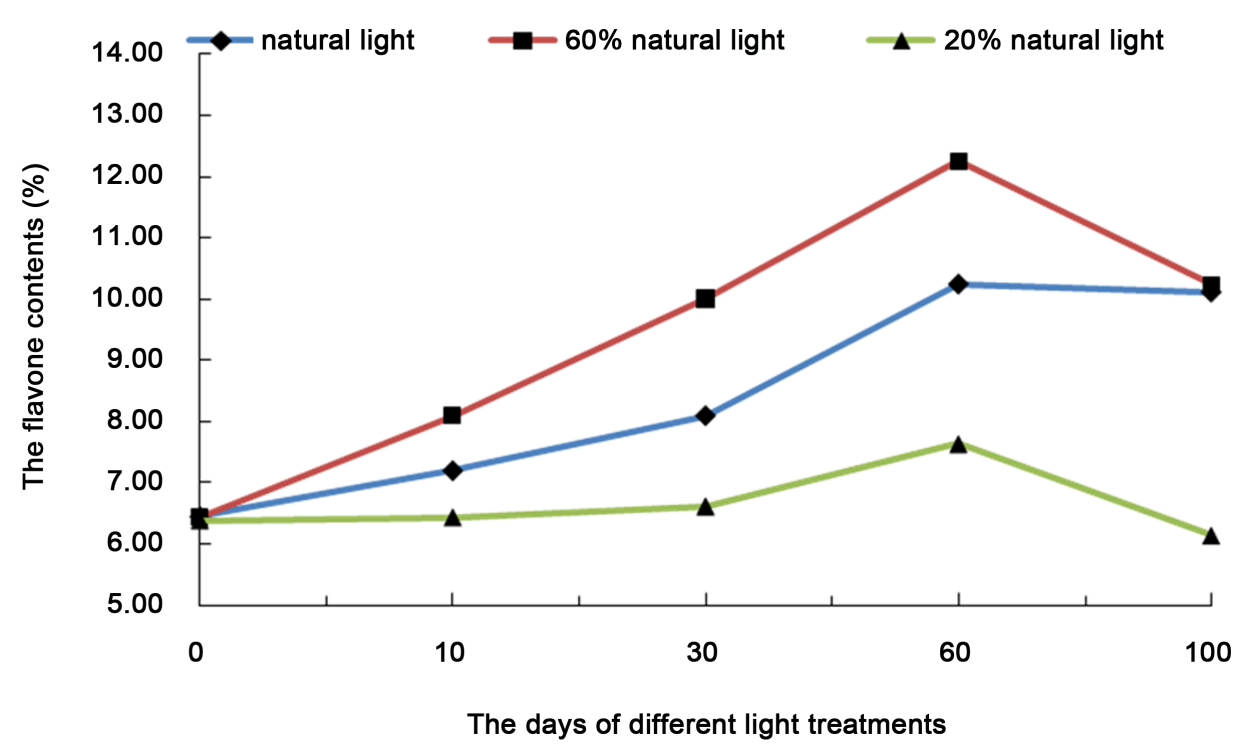

Figure 4. The content of total flavonoids in L. litseifolius under different light treatments.

light energy absorption and conversion and hence a greater ability to utilize weak light (Richardson \& Berlyn, 2002). AQY was highest for the 40\% shading rate, suggesting that $L$. litseifolius could increase the photosynthetic rate through internal regulatory mechanisms in response to reduced light intensity.

Chlorophyll content and $\mathrm{Chl} \mathrm{a} / \mathrm{b}$ ratio are usually used to distinguish between heliophytes and shade plants. For shade plants, the chlorophyll content per unit leaf area is higher, but Chl a/b ratio is lower (Murchie \& Horton, 1998; Baig et al., 2005). The chlorophyll content in L. litseifolius was significantly lower under full light than under shaded conditions; however, the $\mathrm{Chl} \mathrm{a} / \mathrm{b}$ ratio was obviously higher than that under shaded conditions. The changes of leaf photosynthetic rate in the present work showed that L. litseifolius was a heliophyte and was resistant to drought. Under shaded conditions, $\mathrm{Chl}(\mathrm{a}+\mathrm{b}), \mathrm{Chl} \mathrm{a}$ and $\mathrm{Chl} \mathrm{b}$ contents all increased, while the $\mathrm{Chl} \mathrm{a} / \mathrm{b}$ ratio decreased. The increase of chlorophyll content can promote photosynthetic capacity (Bailey et al., 2001). Under shaded conditions, the light saturation point of L. litseifolius is decreased, and the net photosynthetic rate is still the highest (Figure 2). Chlorophyll b is synthesized at a faster rate under weak light conditions, and a relative increase of $\mathrm{Chl}$ b can improve the plant's capacity to utilize red and infrared light. An increase of light-harvesting ability is a form of adaptation of plants to weak light conditions (Bertamini et al., 2006). Thus a decrease in $\mathrm{Chl}$ a/b ratio shows enhanced light absorption capacity under weak light conditions.

\subsection{Influence of Light Intensity on Antioxidant Enzyme System}

The balance of reactive oxygen species (ROS) metabolism is disrupted in plants under stress-the activity of ROS scavengers such as SOD and POD decreases and the ROS content increases (Wang et al., 1989; Maruta et al., 2010). The increase of ROS causes membrane lipid peroxidation, leading to damage to cell membranes. As a product of 
membrane lipid peroxidation, MDA can be used to characterize the degree of this reaction and the plant's response to stress (Zhu et al., 2009). For heliophytes, the light energy utilization rate is $25 \%$ under strong light. However, for shade plants, light saturation is reached at $5 \%$ of strong light, showing a lower light energy utilization rate (Long et al., 1994). Excess light energy causes photooxidation of chloroplasts, which in turn generate ROS that damage the photosynthetic organism (Long et al., 1994; Shirke \& Pathre, 2003). The SOD activity of L. litseifolius was higher under full light than under shaded conditions. Thus, although the photosynthetic capacity was improved compared with shaded conditions, the excess energy light caused the photooxidation of chloroplasts and generation of ROS. Under weak light conditions, the leaves of $L$. litseifolius can efficiently utilize light energy for photosynthesis, which reduces the plant damage caused by ROS. Due to low SOD activity, a large amount of ROS will accumulate, damaging the chloroplast envelope and increasing the MDA content. Shading decreased the POD activity of L. litseifolius, this indicated that under weak-light stress, the dynamic balance between the generation and decomposition of free oxygen radicals was disrupted. The yield of ROS exceeded the scavenging ability of the antioxidant enzyme system, leading to membrane lipid peroxidation and cell damage.

Proteins are the important structural and functional substances in plants, the metabolism of which is regulated by various factors. Increasing evidence shows that a changing environmental factor or stress will influence protein metabolism (Longstreth et al., 1980). The soluble proteins in plants are mostly enzymes involved in metabolic processes. A weakening of light intensity can influence the normal physiological and biochemical processes of plants, leading to the disordered metabolism of proteins. The activity of protective enzymes and the soluble protein content may be reduced under stress, thereby increasing the generation of ROS which damage the cell membrane. With a significant decline in antioxidant ability, the plants will experience rapid senescence. Although L. litseifolius could adapt to weak light conditions by reducing leaf thickness, its tolerance of weak light was limited due to the reduced activity of SOD and POD and the resulting increase of ROS.

\subsection{Influence of Light Intensity on Flavonoid Accumulation}

Flavonoids, which are secondary metabolites, have a protective effect against ultraviolet radiation in plants. As light intensity increases, the intensity of ultraviolet radiation increases accordingly. The plant requires more accumulation of total flavones for stronger protection (Su et al., 2006). In Ginkgo biloba, shading can significantly decrease the content of flavonoid glycosides (Leng et al., 2002). Shading treatment can also reduce total flavone content in Erigeron breviscapus (Su et al., 2006). However, the flavone content in L. litseifolius was not linearly related to light intensity. The flavone content was highest in leaves at $40 \%$ shading rate, and was lower under full light than $80 \%$ shading. It can be inferred that there is an optimal light intensity for accumulation of flavones in L. litseifolius, below or above which the flavone content will decrease.

The variation of flavonoid accumulation differs between plant species, which may be 
related to the complex metabolic pathway of flavonoids. The biosynthesis of flavonoids starts from the phenylpropanoid pathway. Other synthetic pathways are regulated by L-phenylalanine ammonia lyase (PAL), chalcone synthase (CHS), chalcone isomerase (CHI), dihydroflavonol 4-reductase (DFR) and isoflavone synthase (IFS) (Brenda, 2001). In Fagopyrum esculentum, total flavone varies in the same direction as PAL activity (Tang \& Zhao, 1992). Enhanced photosynthesis provides more precursors of secondary metabolites and inhibits the decomposition of secondary metabolites. Therefore, a higher photosynthetic capacity can increase the flavone content in leaves. As an inducible enzyme, PAL can be induced by various factors. In addition to flavonoids, the products of the phenylpropanoid pathway also include lignin and alkaloids (Ouyang \& Xue, 1988). Hence, the flavone accumulation caused by shading may show different features between plant species (Zhao et al., 1999). Although L. litseifolius had its highest photosynthetic capacity under full light conditions, the flavonoid content was not the highest. This may be because it is a heliophyte, and is more easily adapted to full light conditions. Under lower light intensity, the activity of antioxidant enzymes in L. litseifolius decreased, causing increases in ROS. More flavonoids were synthesized to scavenge the ROS, in order to protect the plant.

The content of flavonoids in L. litseifolius leaves was correlated with the time of shading treatment (Figure 4). As the time of shading treatment was prolonged, the content of flavonoids gradually increased. After $60 \mathrm{~d}$ of shading, the content of flavonoids in the leaves began to decrease. A possible reason for this is that the weak-light stress over the long-term caused senescence of cells and the decline of synthetic ability.

\subsection{Selection of Cultivation Sites of L. litseifolius}

Although there will be a decrease of dry weight of a single leaf due to the weakened photosynthetic capacity under weak light, the biomass distribution to leaves will increase (Tao \& Zhong, 2003; Wang \& Wei, 2010). Under 20\% shading rate, the biomass in leaves of entire plants of Catharanthus roseus did not differ significantly from that under full light condition. However, the contents of vindoline and catharanthine increased significantly (Tong et al., 2011). Thus the flavone content was the highest in the leaves of L. litseifolius under $40 \%$ shading rate, and therefore the flavone yield was the highest.

The sun is located more to the south in non-tropical regions in the Northern Hemisphere. Therefore, the South-facing slope receives more light energy than flat ground, which results in a higher total solar radiation and temperature than for the North-facing slope. However, humidity is obviously lower for the South-facing compared to the North-facing slope. For this reason, the South-facing slope is usually called the "sunny slope", and the North-facing the "shady slope". The environmental conditions of East-facing and West-facing slopes lie between those of the South-facing and North-facing slopes. The West-facing slope is illuminated by solar radiation for longer hours in a day than the East-facing slope, and so its environmental conditions are closer to those of the South-facing slope. The West-facing slope is called the "semi-sunny 
slope", and the East-facing slope the "semi-shady slope" (Yin, 2004). The plant communities in South-facing slopes are type of the South flora, showing feature of require less water and greater heat, while plant communities in North-facing slopes can resist cold as the North flora (Yan et al., 2011). As to the aspect, the upper slope receives ample solar radiation and obtains enough heat, which benefits the growth of heliophytes. The lower slope is dominated by high-adaptability or shade-tolerant species (Ma et al., 2010). Lithocarpus litseifolius requires light and also has some resistance to shade. As appropriate shading will induce accumulation of flavonoids, L. litseifolius should be cultivated at lower positions of sunny slopes or upper positions of shady slopes. It could also be cultivated in West-facing and East-facing slopes.

\section{Conclusion}

Lithocarpus litseifolius (Hance) Chun. has high net photosynthetic rate. These features enable L. litseifolius to survive in habitats with sufficient sunlight. After appropriate shading, the leaves of total chlorophyll content increased, while the $\mathrm{Chl} \mathrm{a} / \mathrm{b}$ ratio decreased, as a response to weakened light intensity. Under weak-light stress, SOD and POD had lower activity and the accumulation of free radicals caused cell damage and the rise of intracellular MDA content. In the meantime, the content of soluble proteins declined. Under weak-light stress, L. litseifolius accumulated flavonoids to resist this stress. As the leaves grew, the flavone content of leaves declined. Therefore, L. litseifolius should be cultivated in lower positions of sunny slopes or upper positions of shady slopes to promote accumulation of flavones in leaves.

\section{Acknowledgements}

This work was supported by the Construct Program of the Key Discipline in the Education Department of Hunan Province (201142), Science and Technology Plan Project of Hunan Province (2014NK3109).

\section{References}

Arnon, D. I. (1949). Copper Enzymes in Isolated Chloroplasts: Polyphenoloxidase in Beta vulgaris. Plant Physiology, 24, 1-15. http://dx.doi.org/10.1104/pp.24.1.1

Baig, M. J., Anand, A., Mandal, P. K., \& Bhatt, R. K. (2005). Irradiance Influences Contents of Photosynthetic Pigments and Proteins in Tropical Grasses and Legumes. Photosynthetica, 43, 47-53. http://dx.doi.org/10.1007/s11099-005-7053-5

Bailey, S., Walters, R. G., Jansson, S., \& Horton, P. (2001). Acclimation of Arabidopsis thaliana to the Light Environment: The Existence of Separate Low Light and High Light Responses. Planta, 213, 794-801. http://dx.doi.org/10.1007/s004250100556

Bassman, J., \& Zwier, J. C. (1991). Gas Exchange Characteristics of Populus trichocarpa, Populus deltoides and Populus trichocarpa $\times$ P. deltoides Clone. Tree Physiology, 8, 145-159. http://dx.doi.org/10.1093/treephys/8.2.145

Bertamini, M., Muthuchelian, K., \& Nedunchezhian, N. (2006). Shade Effect Alters Leaf Pigments and Photosynthetic Responses in Norway Spruce (Picea abies L.) Grown under Field Conditions. Photosynthetica, 44, 227-234. http://dx.doi.org/10.1007/s11099-006-0011-z 
Bradford, M. M. (1976). A Rapid and Sensitive Method for the Quantitation of Microgram Quantities of Protein Utilizing the Principle of Protein-Dye Binding. Analytical Biochemistry, 7, 248-254. http://dx.doi.org/10.1016/0003-2697(76)90527-3

Brenda, W. S. (2001). Flavonoid Biosynthesis. A Colorful Model for Genetics, Biochemistry, Cell Biology, and Biotechnology. Plant Physiology, 126, 485-493.

http://dx.doi.org/10.1104/pp.126.2.485

Buege, J. G., \& Aust, S. D. (1978). Microsomal Lipid Peroxiodation. Methods in Enzymology, 52, 302-310. http://dx.doi.org/10.1016/S0076-6879(78)52032-6

Chance, B., \& Maehly, A. C. (1955). Assay of Catalase and Peroxidases. Methods in Enzymology, 2, 764-775. http://dx.doi.org/10.1016/S0076-6879(55)02300-8

Chen, W., \& Huang, C. (1998). Flora Reipublicae Popularis Sinicae (Tomus 22). Beijing: Science Press, 201-203. (In Chinese)

Dai, S. J., Wang, Y., Yan, X. F., \& Ma, M. F. (2004). Effects of Color Films on Growth and Camptothecin Content in the Leaves of Camptotheca acuminata Seedlings. Acta Ecologica Sinica, 24, 869-875. (In Chinese with English abstract)

Dong, H. Q., Li, M., Zhu, F., Liu, F. L., \& Huang, J. B. (2012). Inhibitory Potential of Trilobatin from Lithocarpus polystachyus Rehd against $\alpha$-Glucosidase and $\alpha$-Amylase Linked to Type 2 Diabetes. Food Chemistry, 130, 261-266. http://dx.doi.org/10.1016/j.foodchem.2011.07.030

Gavin, N. M., \& Durako, M. J. (2012). Localization and Antioxidant Capacity of Flavonoids in Halophila johnsonii in Response to Experimental Light and Salinity Variation. Journal of Experimental Marine Biology and Ecology, 416-417, 32-40.

Giannopolitis, C. N., \& Ries, S. K. (1977). Superoxide Dismutases: I. Occurrence in Higher Plants. Plant Physiology, 59, 309-314. http://dx.doi.org/10.1104/pp.59.2.309

Hägele, B. F., \& Rowell-Rahier, M. (1999). Genetic and Environmental-Based Variability in Secondary Metabolite Leaf Content of Adenostyles alliariae and A. alpina (Asteraceae). A Test of the Resource Availability Hypothesis. Oikos, 85, 234-246. http://dx.doi.org/10.2307/3546489

He, C. N., Peng, Y., Xiao, W., Hu, Y. L., \& Xiao, P. G. (2012a). Quick Determination of Five Sweet Constituents in Duosuike Tiancha by RSLC. China Journal of Chinese Materia Medica, 37, 961-965. (In Chinese with English abstract)

He, C. N., Peng, Y., Xiao, W., Yan, Y., Hu, Y. L., \& Xiao, P. G. (2012b). Research Progress in Duosuike Tiancha. Lishizhen Medicine and Materia Medica Research, 23, 1253-1255. (In Chinese with English abstract)

Hou, S. Z., Chen, S. X., Huang, S., Jiang, D. X., Zhou, C. J., Chen, C. Q., Liang, Y. M., \& Lai, X. P. (2011). The Hypoglycemic Activity of Lithocarpus polystachyus Rehd. Leaves in the Experimental Hyperglycemic Rats. Journal of Ethnopharmacology, 138, 142-149.

http://dx.doi.org/10.1016/j.jep.2011.08.067

Hu, X. S., Hong, W., Wu, C. Z., Hong, T., Fan, H. L., \& Song, P. (2006). Response of Structural Plasticity of Schima superba Sapling Crown to Different Light Conditions. Journal of Plant Resources \& Environment, 15, 55-59. (In Chinese with English abstract)

Jiang, C. D., Wang, X., Gao, H. Y., Shi, L., \& Chow, W. S. (2011). Systemic Regulation of Leaf Anatomical Structure, Photosynthetic Performance, and High-Light Tolerance in Sorghum. Plant Physiology, 155, 1416-1424. http://dx.doi.org/10.1104/pp.111.172213

Leng, P. S., Su, S. C., Wang, T. H., Jiang, X. N., \& Wang, S. S. (2002). Effects of Light Intensity and Light Quality on Photosynthesis, Flavonol Glycoside and Terpene Lactone Contents of Ginkgo biloba L. Seedlings. Journal of Plant Resources and Environment, 11, 1-4. (In Chinese with English abstract) 
Li, S. H., Wu, X. J., \& Xiang, X. J. (2010). Study on Activity Contents and Bacteriostasis Function of Lithocarpus polystarch. Food Science and Technology, 35, 211-214. (In Chinese with English abstract)

Li, S. H., Wu, X. J., Yu, J. P., Li, S. Y., \& Han, Y. G. (2008). Study on Extraction Technics and Content Variety Trends of Total Flavonoids in Lithocarpus polystachyus Rehd. Food Science, 29, 139-141. (In Chinese with English abstract)

Liu, S. L., Ma, M. D., Pan, Y. Z., Wei, L. L., He, C. X., \& Yang, K. M. (2012). Effects of Light Regimes on Photosynthetic Characteristics and Antioxidant System in Seedlings of Two Alder Species. Chinese Journal of Plant Ecology, 36, 1062-1074. (In Chinese with English abstract) http://dx.doi.org/10.3724/SP.J.1258.2012.01062

Long, S. P., Humphries, S., \& Falkowski, P. G. (1994). Photoinhibition of Photosynthesis in Nature. Annual Review of Plant Physiology and Plant Molecular Biology, 45, 633-662. http://dx.doi.org/10.1146/annurev.pp.45.060194.003221

Longstreth, D. J. (1980). Nutrient Influence on Leaf Photosynthesis Effects on Nitrogen Phosphorus and Potassium for Gossypium hirsutrum L. Plant Physiology, 65, 541-543.

http://dx.doi.org/10.1104/pp.65.3.541

Ma, X. D., Zhang, S. J., Su, Z. Y., Ou, Y. D., \& Liu, G. (2010). Community Structure in Relation to Microtopography in Amontane Evergreen Broadleaved Forest in Chebaling National Nature Reserve. Acta Ecologica Sinica, 30, 5151-5160. (In Chinese with English abstract)

Maruta, T., Tanouchi, A., Tamoi, M., Yabuta, Y., Yoshimura, K., Ishikawa, T., \& Shigeoka, S. (2010). Arabidopsis Chloroplastic Ascorbate Peroxidase Isoenzymes Play a Dual Role in Photoprotection and Gene Regulation under Photooxidative Stress. Plant \& Cell Physiology, 51, 190-200. http://dx.doi.org/10.1093/pcp/pcp177

Murchie, E. H., \& Horton, P. (1998). Contrasting Patterns of Photosynthetic Acclimation to the light Environment Are Dependent on the Differential Expression of the Responses to Altered Irradiance and Spectral Quality. Plant, Cell \& Environment, 21, 139-148. http://dx.doi.org/10.1046/j.1365-3040.1998.00262.x

Ouyang, G. C., \& Xue, Y. L. (1988). Physiological Role and Regulation of Phenylpropanoid Metabolism in Plant. Plant Physiology Communications, 3, 9-16. (In Chinese with English abstract)

Pengelly, J. J. L., Sirault, X. R. R., Tazoe, Y., Evans, J. R., Furbank, R. T., \& von Caemmerer, S. (2010). Growth of the $\mathrm{C}_{4}$ Dicot Flaveria bidentis: Photosynthetic Acclimation to Low Light through Shifts in Leaf Anatomy and Biochemistry. Journal of Experimental Botany, 61, 41094122. http://dx.doi.org/10.1093/jxb/erq226

Ren, H., Li, X., Xing, Z. T., Ke, Y. C., Bai, D. J., \& Cao, B. (2012). Preparation of a Compound Teabag with Ilex kudingcha、 Lithocarpus polystachyus Rehd and Green Tea. Food Industry, 33, 78-79. (In Chinese with English abstract)

Richardson, A. D., \& Berlyn, G. P. (2002). Spectral Reflectance and Photosynthetic Properties of Betula papyrifera (Betulaceae) Leaves along an Elevational Gradient on Mt. Mansfield, Vermont, USA. American Journal of Botany, 89, 88-94. http://dx.doi.org/10.3732/ajb.89.1.88

Shirke, P. A., \& Pathre, U. V. (2003). Diurnal and Seasonal Changes in Photosynthesis and Photosystem 2 Photochemical Efficiency in Prosopis juliflora Leaves Subjected to Natural Environmental Stress. Photosynthetica, 41, 83-89. http://dx.doi.org/10.1023/A:1025864513663

Su, W. H., Zhang, G. F., Li, X. H., Gu, F.X., \& Shi, B. L. (2006). Effect of Light Intensity and Light Quality on Growth and Total Flavonoid Accumulation of Erigeron breviscapus. Chinese Traditional and Herbal Drugs, 37, 1244-1247. (In Chinese with English abstract)

Tang, Y., \& Zhao, G. (1992). Relationship between Phenylalanine Ammonialyase Activity and 
Flavone Content in Buckwheat. Plant Physiology Communications, 28, 419-420. (In Chinese with English abstract)

Tao, J. P., \& Zhong, Z. C. (2003). Effects of Light on Morphological Plasticity and Biomass Allocation of Momordica charantia. Chinese Journal of Applied Ecology, 14, 336-340. (In Chinese with English abstract)

Tong, L., Zhang, B. Y., Tang, Z. H., Guo, X. R., Jia, X. Y., \& Yu, J. H. (2011). Effects of Low Light Stress on the Biomass Distribution and Secondary Metabolism of Catharanthus roseus. Bulletin of Botanical Research, 31, 227-230. (In Chinese with English abstract)

Wang, B. Y., Ma, H. J., Su, T. W., Liu, T., \& Wang, Q. (2012). Physiological Response and Acclimation to Changes in Light Regimes in Two Tropical Rainforest Species. Plant Physiology Journal, 48, 232-240. (In Chinese with English abstract)

Wang, J. H., Liu, H. X., \& Xu, T. (1989). The Role of Superoxide Dismutase (SOD) in Stress Physiology and Senescence Physiology of Plant. Plant Physiology Communications, 25, 1-7. (In Chinese with English abstract)

Wang, Y., \& Wei, X. L. (2010). Advance on the Effects of Different Light Environments on Growth, Physiological Biochemistry and Morphostructure of Plant. Journal of Mountain Agriculture and Biology, 29, 353-359. (In Chinese with English abstract)

Xie, Z. W. (1987). Directory of Traditional Chinese Medicinal Herbs (Part II) (p. 256). Beijing: People's Medical Publishing House. (In Chinese)

Xue, W., Li, X.Y., Zhu, J.T., Lin, L.S., \& Wang, Y.J. (2011) Effects of Shading on Leaf Morphology and Response Characteristics of Photosynthesis in Alhagi sparsifolia. Chinese Journal of Plant Ecology, 35, 82-90. (In Chinese with English abstract)

http://dx.doi.org/10.3724/SP.J.1258.2011.00082

Yan, X. F., Wang, Y., \& Shang, X. H. (2003). Effects of Greenhouse Light Intensity and Quality on Biomass and Salidroside Content in Roots of Rhodiola sachalinensis. Acta Ecologica Sinica, 23, 841-849. (in Chinese with English abstract)

Yan, X. F., Wang, Y., Shang, X. H., Guo, S. L., \& Yu, T. (2004). Effects of Field Light Intensity and Quality on Biomass and Salidroside Content in Roots of Rhodiola sachalinensis. Acta Ecologica Sinica, 24, 674-679. (In Chinese with English abstract)

Yan, Y. H., He, Z. X., Yuan, H., \& Xing, F. W. (2011). The Ecological Response of Fern Diversity to Different Slopes in Gudoushan Nature Reserve, Guangdong. Biodiversity Science, 19, 41-47. (In Chinese with English abstract) http://dx.doi.org/10.3724/SP.J.1003.2011.07109

Yin, X. Q. (2004). Biogeography (pp. 26-28). Beijing: Higher Education Press. (In Chinese with English abstract)

Zhao, D. X., Li, M. Y., Xing, J. M., \& Tong, Z. (1999). Effects of Light on Cell Growth and Flavonoids Biosynthesis in Callus Cultures of Saussurea medusa Maxim. Acta Photophysiologica Sinica, 25, 127-132. (In Chinese with English abstract)

Zhao, J., Zhu, W. H., \& Hu, Q. (2001). Effects of Light and Plant Growth Regulators on the Biosynthesis of Vindoline and Other Indole Alkaloids in Catharanthus roseus Callus Cultures. Plant Growth Regulation, 33, 43-49. http://dx.doi.org/10.1023/A:1010722925013

Zhu, L. J., Su, Z. X., Hu, J. Y., \& Su, R. J. (2009). Peroxidase Activity and MDA Content of Endangered Species Davidia involucrata. Chinese Journal of Ecology, 28, 451-455. (In Chinese with English abstract) 
Submit or recommend next manuscript to SCIRP and we will provide best service for you:

Accepting pre-submission inquiries through Email, Facebook, LinkedIn, Twitter, etc. A wide selection of journals (inclusive of 9 subjects, more than 200 journals)

Providing 24-hour high-quality service

User-friendly online submission system

Fair and swift peer-review system

Efficient typesetting and proofreading procedure

Display of the result of downloads and visits, as well as the number of cited articles

Maximum dissemination of your research work

Submit your manuscript at: http://papersubmission.scirp.org/

Or contact ojf@scirp.org 